\section{Unification of Equipment for Transporting People, Coal and Materials Produced by Jastrzębskie Zakłady Remontowe Sp. z o. 0. and Used in the Mines of the JSW Capital Group}

\author{
Artur Dyczko, Rafał Rychter, \\ Adam Bosowski, Jarosław Konsek \\ Jastrzębska Spółka Węglowa Capital Group, \\ Jastrzębskie Zakłady Remontowe Sp. z o. o., Poland
}

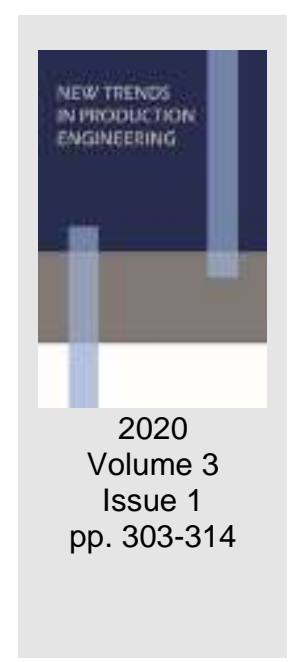

Date of submission to the Editor: 02/2020

Date of acceptance by the Editor: 03/2020

\title{
INTRODUCTION
}

As per the definition in the Słownik Języka Polskiego ("Dictionary of the Polish Language"), unification means the homogenization of something, reducing it to one form or standard, or combining various elements into one whole, integrating, uniting. Can unification also apply to equipment and machinery, what benefits and risks can it bring to the JSW Group, how to make it effective, and is it related to innovation, i.e. technical development of equipment and machinery intended for transporting people, coal and materials? The answers to these questions, developed on the example of the unification process already implemented by Jastrzębskie Zakłady Remontowe Sp. z o. o., constitute the main content of this study.

In the years 2015-2018, the JSW Group noted a significant increase in the prices of purchased equipment and machinery for transporting people, coal and materials. Furthermore, the purchasing procedures in force in Poland (Journal of Laws 2019.0.1843 i.e. - Act of 29 January 2004) led to the situation that new equipment was supplied by different manufacturers, and thus differed in design and construction (in some cases even devices purchased from the same manufacturer were of two different models, despite identical requirements included in the ToR of the announced tenders). This led to a situation in which every mine was forced to keep a very extensive and constantly growing stockpile of spare parts acquired with the new equipment. Moreover, in most cases, these parts could not be used for new equipment, so they constituted the so-called 'frozen capital,' which was, in principle, unrecoverable. However, the diversity of equipment is more than just a problem of parts interchangeability; in 2017, the "Krupiński" JSW mine in Suszec closed down, and its mining staff were deployed in other mines belonging to JSW S.A. Then, it turned out that the diversity of machines is also a problem for the operating team. Workers transferred to different mines had to be retrained in the design and operation 
of devices they had not used before, even though they had many years of operating experience on similar equipment. The need for new training and the so-called "learning the machine" did not only concern the relocated employees. The equipment and machinery of the closed "Krupiński" mine, which was still in good technical condition (as well as the stockpile of associated spare parts), was transferred to other mines of the JSW Group, which in turn made it necessary to train local staff on the machines in question.

Confronting these problems, the JSW Capital Group decided to entrust Jastrzębskie Zakłady Remontowe Sp. z o. o. with the mission of carrying out the process of unification of all equipment and machinery for transporting people, coal and materials at all mines belonging to the Company, ensuring maximum use of their machinery stocks.

\section{UNIFICATION - HOW TO DO IT?}

In response to the new expectations, the Management Board of Jastrzębskie Zakłady Remontowe Sp. z o. o. decided to expand its current activities consisting mainly in overhaul and modernization (primarily of powered roof support sections) for the mines of the JSW Group, and move into the production of new elements and complete transport devices. For this purpose, the PROGRAM ROZWÓJ development program was created, with the aim to build new production halls and create a modern machine park located on the premises of the former "Krupiński" mine in Suszec (E. Milewska 2017). The program involves starting the production of new unified panlines for chain conveyors, rollers for belt conveyors, elements of main pressure and run-off pipelines, rails for overhead conveyors, and elements of powered support sections as early as in 2020.

However, the unification process is not limited to the five new products mentioned above. In order to carry out full unification of all equipment and machinery for transporting people, coal and materials used mainly as elements of the coal clearance systems, the PROJEKT PRZENOŚNIKI ("Conveyors Project") was created as part of the PROGRAM ROZWÓJ, with the aim to design, manufacture and implement new complete devices of the coal clearance system, such as an armored face conveyor, beam stage loader, belt conveyor, rescue conveyor and supporting devices, i.e. lump breakers and pushing devices. As part of this project, already in 2018, JZR created a new Conveyor Design Department, composed of a group of experienced engineers with extensive technical knowledge on the design of this type of equipment. The newly appointed team, together with representatives of JSW and all the mines of the JSW Group (J. Ligarski 2017), reviewed the transport equipment owned and operated at the mines, and then jointly developed directions for the unification of the equipment produced by JZR, with a view to making maximum use of elements already owned. As a result of the work, a study has been prepared (extract presented in Table 1) describing in detail the direction of unification, which applies both to the elements produced by JZR and purchased elements such as: electric motors, couplings, gearings, chains, belts, etc. 
Table 1 Extract from: "Concept design and feasibility study for the production of unified conveying equipment by JZR"

Armoured Face Conveyor:

\begin{tabular}{|c|c|c|}
\hline TYPE & PSJZR-850 & PSJZR-1100 \\
\hline Discharge & \multicolumn{2}{|l|}{ front and/or side } \\
\hline Engines & \multicolumn{2}{|l|}{$105 / 315 \quad 200 / 400 \quad 260 / 520$} \\
\hline Gearbox & \multicolumn{2}{|l|}{$, 25 " \mathrm{i}=33 \quad, 35 " \mathrm{i}=39$} \\
\hline Couplings & \multicolumn{2}{|l|}{ flexible } \\
\hline Chain & $34 \times 126,38 \times 126$ flat & $38 \times 126$ flat, $42 \times 146$ flat \\
\hline Profile & E270 & $\mathrm{E} 300$ \\
\hline Slide/locking plate & $45 / 25$ & $50 / 30$ \\
\hline Vertical correction & sphere/fork & sphere/fork \\
\hline Panline length & 1500 & 1750 \\
\hline Haulage ladder system & \multicolumn{2}{|l|}{$p=125$} \\
\hline \multicolumn{3}{|l|}{ Beam Stage Loader: } \\
\hline TYPE & PPJZR-850 & PPJZR-1100 \\
\hline Engines & \multicolumn{2}{|l|}{$85 / 250 ; 105 / 315 ; 200 / 400$} \\
\hline Gearbox & \multicolumn{2}{|l|}{${ }_{, 15} 15^{\prime} \mathrm{i}=21 ;, 25^{\prime \prime} \mathrm{i}=21$} \\
\hline Couplings & \multicolumn{2}{|l|}{ flexible } \\
\hline Chain & $30 \times 108 ; 34 \times 126$ & $34 \times 126 ; 38 \times 126$ flat \\
\hline Profile & E260 & E285 \\
\hline Skid/locking plate & $(40) 45 / 25$ & $50 / 30$ \\
\hline Bridge & \multicolumn{2}{|l|}{ rigid/flexible } \\
\hline Tightening & \multicolumn{2}{|c|}{ Telescopic return/discharge attachment } \\
\hline
\end{tabular}

\section{Lump Breakers}

\begin{tabular}{|l|l|ll|}
\hline Belt-drive KUJZR-3(4,5)p & Gear-drive KUJZR-3(4,5)z & \\
\hline Engines & $\max 1 \times 250 \mathrm{~kW}$ & Engines & $\max 2 \times 250 \mathrm{~kW}$ \\
\hline Transmission & belt drive & Transmission & toothed gear \\
Coupling & slip & Coupling & flexible/hydraulic \\
Number of hammers & $3,4,5$ & Number of hammers & $3,4,5$ \\
Length & $3.0 \mathrm{~m}$ & Length & $3.0 \mathrm{~m}$
\end{tabular}

Belt Conveyor:

\section{PTJZR-1000 (1200)}

\begin{tabular}{|l|l|}
\hline Belt width & 1000 or 1200 \\
\hline Belt type & 4 ply \\
\hline Route & C-shaped/line \\
\hline Belt storage cassette & 55 running metres \\
\hline Belt speed & $3.16 \mathrm{~m} / \mathrm{s}$ \\
\hline Possibility of transporting people & as an option on the top belt \\
\hline
\end{tabular}


The study has been approved and accepted for implementation by the management of all mines.

\section{ASSUMPTION OF THE UNIFICATION}

The scope of unification of the equipment and machinery for transporting people, coal and materials involved in this process must also be closely linked to the geological conditions of the mining excavations in which the equipment will be operated. Therefore, the assumptions of unification include percentage thresholds (Fig. 1) for the newly developed devices.

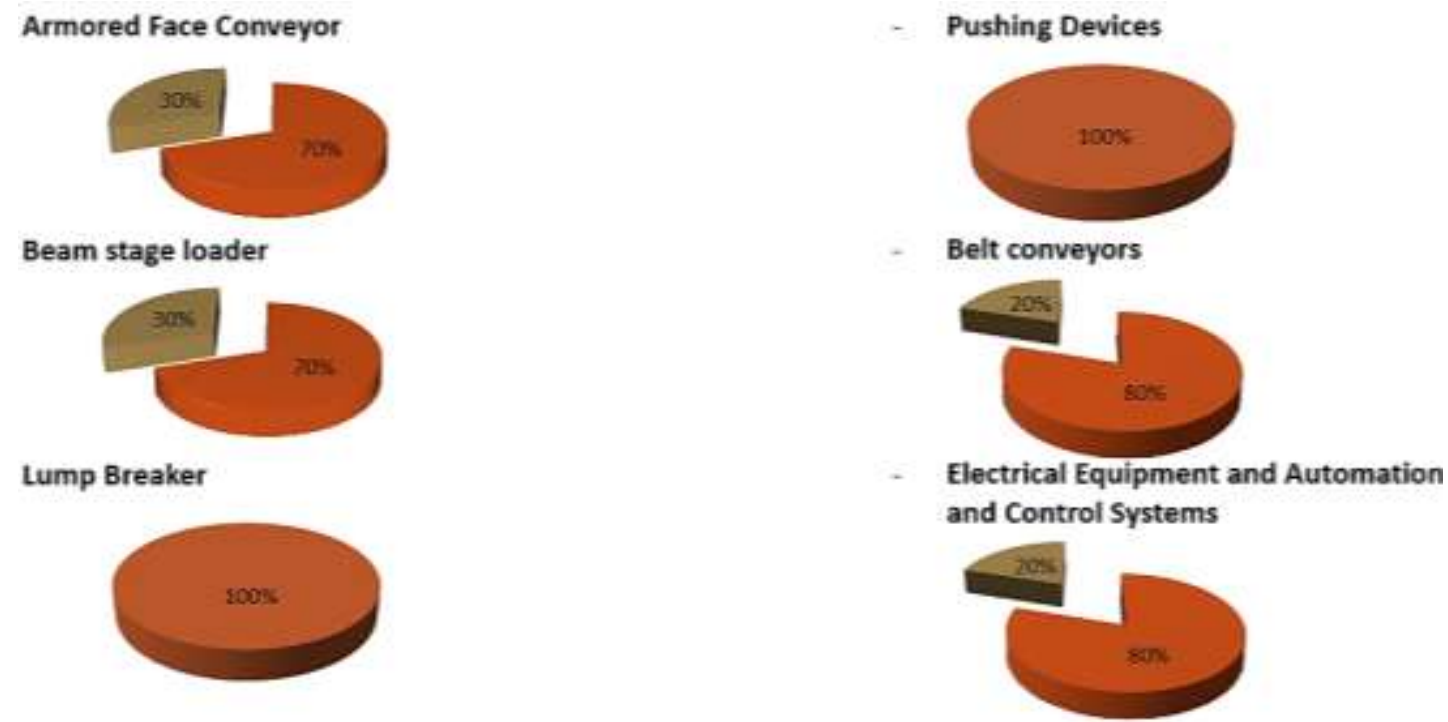

Fig. 1 Assumed percentage share of unification in the construction of equipment Source: (J. Antoniak, J. Suchoń 1983, P. Kulinowski, J. Suchoń 2012, P. Świerk \& K. Foks \& M. Wilczak \& W Ziewiecki 2016)

It has been assumed that along with the expected percentage share of the unification (depending on the given local conditions of individual devices), the process should also consider the so-called type ranges, and from among the many currently used types of machines, choose those which constitute the largest share in the present coal clearance systems (Fig. 2).

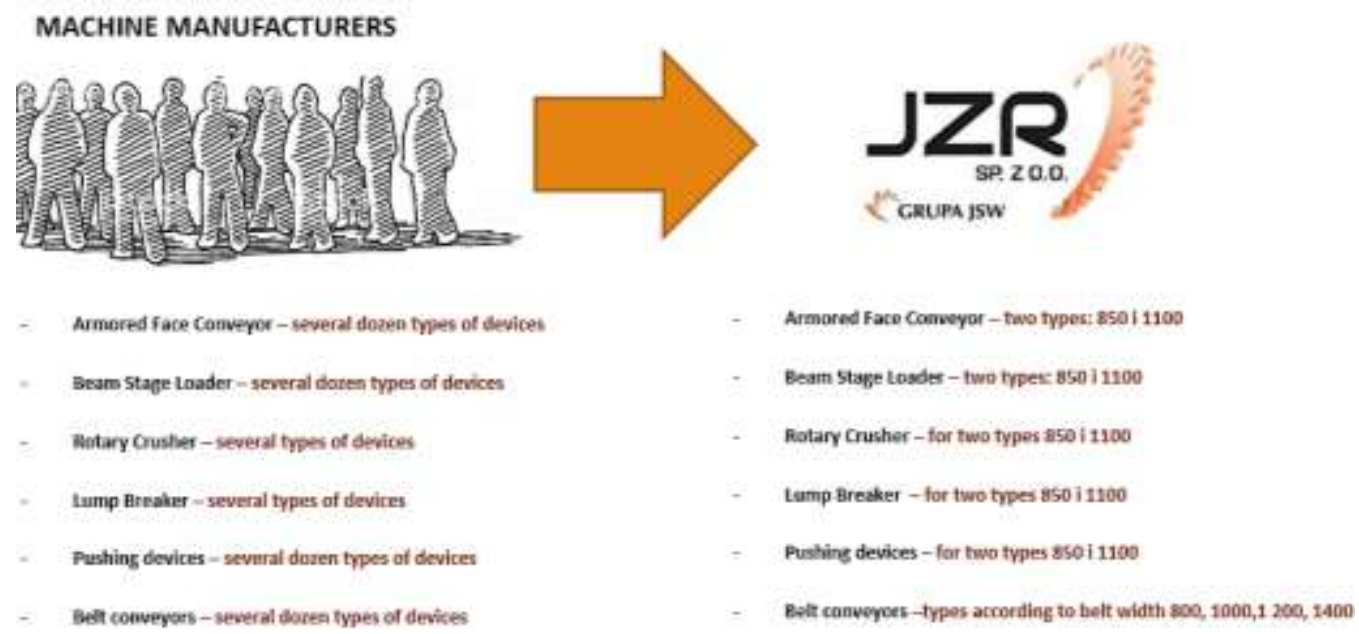

Fig. 2 The course of unification process 
The selected types were also presented in the Study submitted to the management of mines of the JSW Capital Group.

\section{BENEFITS OF UNIFICATION}

The unification of equipment and machinery for transporting people, coal and materials is a process to be implemented over a more extended period and it depends on the so-called "natural technical death" of equipment not produced by JZR and used at the mines of JSW Capital Group. The benefits of the process can be realistically estimated only after it is fully implemented. However, it can already be predicted that these benefits will include:

- Full interchangeability of machine parts, i.e. the possibility of "transfers" among mines,

- Smaller, uniform stock of parts - spare parts and fast-wearing parts,

- Smaller variety of elements purchased from external suppliers (possibility of a discount when purchasing a larger quantity of a given part),

- Availability of spare parts,

- Standardized design of equipment (employee training).

An additional benefit, resulting not from the unification itself, but rather from the decision of the JSW S.A. Management Board to entrust the production of unified transport equipment to Jastrzębskie Zakłady Remontowe, is undoubtedly the lower purchase price of the equipment. The cost of devices produced by JZR so far for the mines of "Knurów-Szczygłowice", "Borynia-Zofiówka" and others was lower than the current market price of similar equipment by $12-18 \%$, depending on the number of components purchased from external suppliers. Moreover, it should be noted that the purchases from JZR were made according to the so-called "in house" formula, provided for in Article 136 of the Public Procurement Law (Art. 136. Journal of Laws 2019.0.1843). This procurement method offers additional benefits, such as:

- High flexibility in meeting the needs of the mines (adapting to the schedule of individual mines, saving time for JSW procedures, financing in line with the needs of the mines (e.g. investments or overhaul),

- The possibility of changing an order from one to another if required by the mine (in the case of a tender there is no such possibility),

- Proper quality of manufactured products through the use of high-quality materials; in tenders, bidders focus only on minimizing costs, which is always at the expense of quality, and thus means shorter service life of equipment,

- Extended warranty within the JZR "Rozwój" development program,

- Quick response to complaints,

- Tailoring to the needs (even during order execution, it is possible to make some changes; in tenders, it is not possible),

- Possibility to withdraw completely from a contract; in case of a tender, it is problematic,

- Determining at the procurement stage the specific solutions and recommendations of the ordering party to suit its individual requirements, 
- Utilizing equipment and machinery components not currently used by mines,

- Aggregating orders of one type - optimal production planning (predictability will affect price, punctuality and quality),

- The JZR margin stays within the Group and can be used for R\&D; liquidity support and increasing the value of the Company and thus the JSW Group,

- With maintaining more staff resources, the flexibility of response to JSW'S also increases (urgent orders, changing production plans, etc.),

- Cost predictability for JSW.

\section{POTENTIAL RISKS DUE TO UNIFICATION}

It should be noted that the introduction of the unification of transport equipment and machinery in the mines of the JSW Group involves not only benefits. From the very beginning of the process, the teams responsible for its implementation have to work out solutions to minimize the risks, which concern, among others, the following issues:

- Lack of product development after the unification process,

- Dependence on just a few sub-suppliers of outsourced components such as gears, couplings, motors, forged and cast parts, etc., which over time may result in price increases of those components,

- Shortage of particular outsourced components in case of e.g. withdrawal of a specific sub-supplier from the market,

- Being closed to "technological thought" in line with new global trends in mining technology.

- The risk of "prototype implementation".

These are only some of the issues which require early planning of an appropriate counteraction scenario (D. Palka \& A. Wieczorek 2017). Therefore, for the success of the whole process, it is essential to accurately monitor conducted activities and their perceptible results, perform their quick analysis and, if necessary, introduce corrections. All of this is carried out during regular meetings of specially designated teams of employees, including representatives of JSW, JZR, all the mines and the ZWP Production Support Plant.

\section{UNIFICATION AND INNOVATION}

Along with the idea of unification, the equipment manufactured by JZR incorporates several innovative solutions aimed at improving both its reliability and safety conditions (M. Krauze 2017) for operating staff. When designing the transport equipment, JZR engineers, together with technical services from the mines, make appropriate technical analyses (J. Suchoń 2012, D. Szurgacz \& P. Szolc \& G. Cuber 2019) and introduce new, often innovative solutions based mainly on long-term experience of employees using similar machines. The solutions worked out together so far include:

- Sprocket wheel made of forgings or wear-resistant sheet metal with optimized shape of teeth determined based on experimental studies of chain 
links position (P. Sobota \& R. Mann \& A. Bujnowska 2018, A.N. Wieczorek \& W. Polis 2015)

- drum lubrication system integrated into the frame of driving device,

- Sprinkler system integrated into the frame of driving device,

- Small-sized toothed coupling,

- New power transmission solution in a chain conveyor (K. Filipowicz \& M. Kuczaj 2017, A. Marek 2017),

- New solution for inspection plates on the discharge attachment,

- New solution for inspection plates on the return drive and the return,

- Hydraulic maneuvering device,

- Broken-chain locking system,

- New valve solution with optimized design adapted to work with UPZ-1 devices (D. Wyciszczok \& S. Wyciszczok \& B. Karczkowski 2016),

- New power transmission solution in a chain conveyor (V. Moni \& P. Klouda \& V. Skraban 2013),

- Optimized platforms for boarding and disembarking a conveyor belt,

- Impact-resistant beds at transfer points made of new materials used in mining (D. Adamecki 2017),

- Self-cleaning return drum of a belt conveyor,

- Reinforced rollers of a belt conveyor,

- New design of driving pulleys with ceramic lagging (J. Jurman \& I. Cholevová \& I. Onderková. 2013, J. Jurman \& T. Hapla 2016),

- "Click" belt conveyor routes,

- Exchangeable skids of lump breakers,

- Exchangeable working plate for lump breakers

- New power transmission solution for lump breakers,

- New locking system in pushing devices,

- New type of crown of telescopic struts used for anchoring,

- Trough roller conveyor system in mobile belt tail pieces,

- and others.

It is worth noting that the new innovative technical solutions introduced are not limited to a particular application. The idea of unification allowed for the development of solutions which, with a minimum increase in the cost of production of a given element, allow for its use in configurations which have not been possible so far, which leads to measurable benefits in the form of savings on subsequent purchases. An excellent example of this is the innovative solution of the frame of driving device and the discharge attachment (Fig. 3) used in beam stage loaders. Thanks to the use of additional mounting plates, it is possible to install the same discharge part of the conveyor, both supporting it under the frame (installation on the PTJZR-SZL1 mobile belt tail piece) and supporting it under the attachment (installation on the PTJZR-SZL1 line turning station). This allows both elements to be fully utilized regardless of the current configuration of the device (Fig. 4). 


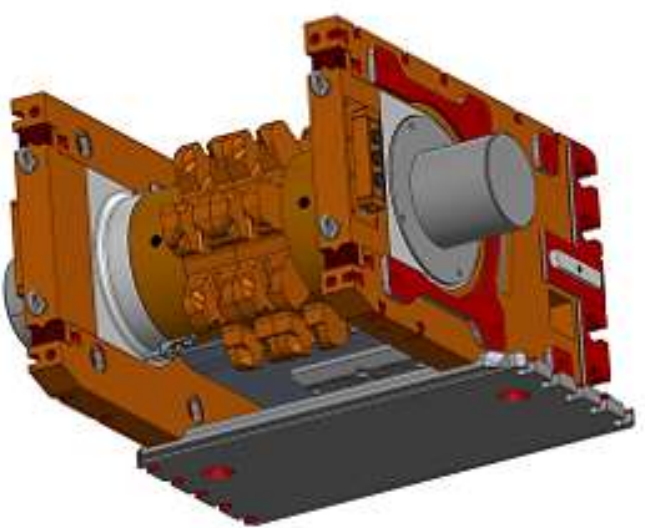

Drive Unit Frame

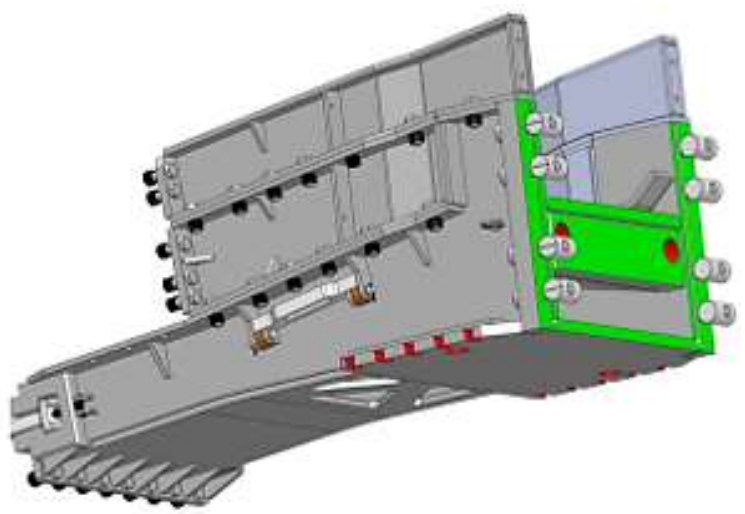

Discharge Attachment

Fig. 3 Innovative solution for frame of driving device and discharge attachment

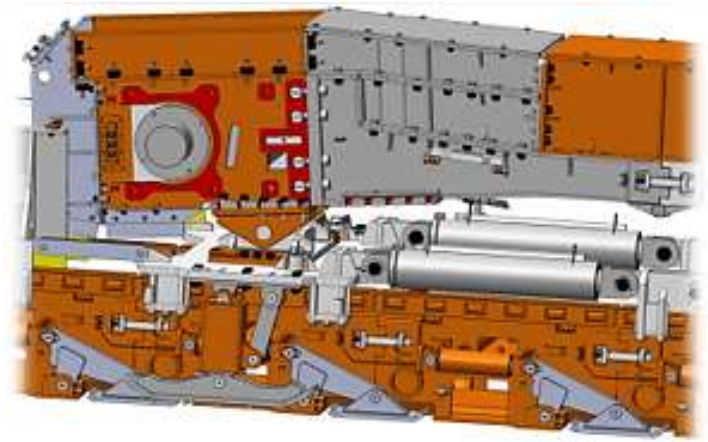

Installation on Drive Unit Frame

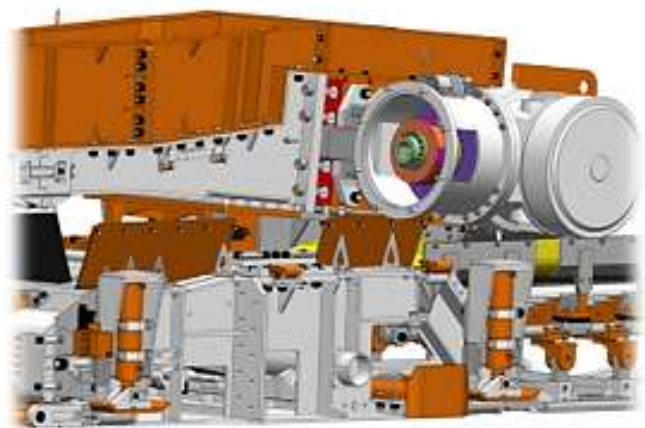

Installation on Discharge Attachment

Fig. 4 Examples of installation on driving device frame and discharge attachment

The joint efforts of the design team, i.e. engineers, technologists and mine services, are aimed at developing transport devices that, to the greatest extent, 
meet the technical needs of the mines and, at the same time, provide highly reliable and safe solutions.

\section{OPTIMIZATION OF PRODUCTION COSTS IN RELATION TO SERVICE LIFE AND QUALITY}

The unification of equipment for transporting people, coal and materials carried out in the JSW Group assumes the production of products which are the cheapest not only at the time of their purchase, but throughout their entire service life. In order to achieve this goal, it was decided to optimize selected production stages and processes (K. Filipowicz \& M. Kuczaj 2017, K. Midor \& G. Klimasara 2016) and so the optimization covered:

- The stage of selection of construction materials (optimization of quality and thickness of metal sheets),

- The stage of predicting the assumed service life of operating components,

- The stage of selection of cooperating elements, e.g. class and type of scraper chains, type of couplings, gearbox speeds, engine power, etc.,

- The stage of selection of purchased elements - class of bolts and nuts, quality of bearings, forgings and castings, etc.,

- Technological processes (bending, welding, etc.).

All these activities aim at increasing the service life of machines and equipment produced by JZR, assuming, at the same time, an increase in the technical culture and awareness of operating staff obtained thanks to a training package implemented in the mines concerning the operation and maintenance of new elements of the coal clearance systems $(H$. Badura \& A. Michna \& S. Czerwiński 2016).

\section{CONCLUSIONS}

On 26.09.2019 the Management Board of Jastrzębskie Zakłady Remontowe, a member of the JSW Group, presented to the directors of mines and to the JSW Management Board the first-ever unified devices of the coal clearance system, which were delivered to the "Borynia" section of "Borynia-ZofiówkaJastrzębie" mine. The provided equipment constitutes a longwall system consisting of the PPJZR-850 beam stage loader, the KUJZR-4z lump breaker, the UPJZR-KP1200 pushing device and the PTJZR-SZL1 line turning station. All of the above machines initiated a real process of unification of the coal clearance systems, which JSW S.A. decided to introduce in all its mines. It should be noted that the entire design and manufacturing process of all the equipment has been carried out at Jastrzębskie Zakład Remontowe, with the use of the highest quality materials, some commonly known and some first-used in the mining industry.

The delivery of equipment for the "Borynia" mine was the beginning of the unification process that JSW S.A. wants to introduce in its mines using the help of JZR. Since the delivery of equipment to the "Borynia" section of the "BoryniaZofiówka-Jastrzębie" mine, Jastrzębskie Zakłady Remontowe has already 
launched and delivered to the "Knurów-Szczygłowice" mine, "Knurów" section, and the "Borynia-Zofiówka" mine, "Borynia" section, complete panlines for the 850 armored face conveyors and a mobile belt tail piece for the "Zofiówka" section. Currently, works are carried out on the unification of further equipment such as the PSJZR 1100 armored face conveyors, KSJZR longwall crushers, PTJZR belt conveyors and PRJZR rescue conveyors. It should be noted that in parallel with these works, an investment is carried out in the Suszec municipality, where, in the second half of 2020, JZR plans to launch the production of new parts of the unified machinery and equipment.

\section{REFERENCES}

Journal of Laws (2019).0.1843 i.e. - Act of 29 January 2004 - Public procurement law Art. 136. Journal of Laws 2019.0.1843 - Public procurement law

Słownik Języka Polskiego. Wydawnictwo Naukowe PWN

D. Adamecki. (2017) Oddziaływanie między urobkiem i taśmą w górniczych przenośnikach taśmowych - wybrane zagadnienia. Systems Supporting Production Engineering No. 6(2) Zagadnienia energomaszynowe i bezpieczeństwo w górnictwie

J. Antoniak, J. Suchoń. (1983) Górnicze przenośniki zgrzebłowe. Śląsk"

H. Badura, A. Michna, S. Czerwiński. (2016) Proces przygotowania pracowników do podjęcia bezpiecznej pracy na przykładzie kopalni. Systemy Wspomagania w Inżynierii Produkcji Volume 1(13)

K. Filipowicz, M. Kuczaj. (2017) Wpływ metalowego sprzęgła podatnego na wybrane parametry rozruchu układu napędowego. Systemy Wspomagania w Inżynierii Produkcji Vol. 6; Iss. 2

J. Jurman, I. Cholevová, I. Onderková. (2013) Efficiency increasing of belt conveyor's drive by ceramic lagging of driving pulley. Management Systems in Production Engineering No. 3(11)

J. Jurman, T. Hapla. (2016) Obložení bubnů pásových dopravníků a jeho vliv na přenos tažné síly. Systemy Wspomagania W Inżynierii Produkcji Z1; (13)

M. Krause. (2017) Badania zróżnicowania ryzyka wypadków przy pracy na przykładzie analizy statystyki wypadków dla branży górnictwa i Polski. Systems Supporting Production Engineering No. 6(2) Zagadnienia energomaszynowe i bezpieczeństwo w górnictwie

P Kulinowski. Systemy i urządzenia transportowe - górnictwo podziemne - didactic materials of Akademia Górniczo-Hutnicza

J. Ligarski. (2017) Production engineering as a discipline and the possibilities to apply the organization of its achievements in practice. Systemy Wspomagania w Inżynierii Produkcji Vol. 6; Iss. 4

A. Marek. (2017) Wpływ przemienników częstotliwości na pracę silników indukcyjnych w podziemiach kopalń. Systemy Wspomagania w Inżynierii Produkcji Vol. 6; Iss. 2

E.W. Maruszewska, W. Biały (2017) Financial challenges in production engineering using key performance indicators - a case of different production process types. Systems Supporting Production Engineering Nr 6(24) Cross-Border Exchange of Experience in Production Engineering Using Principles of Mathematics

E. Milewska. (2017) Zdolność adaptacyjna przedsiębiorstw produkcyjnych. Systemy Wspomagania w Inżynierii Produkcji Vol.6; Iss. 6

K. Midor, G. Klimasara. (2016) Mapa procesu jako innowacyjne narzędzie optymalizacji jakościowej procesu produkcji. Systemy Wspomagania w Inżynierii Produkcji Vol. 64; Iss. 16 
V. Moni, P. Klouda, V. Skraban (2013) Comprehensive check measurement of key parameters on model belt conveyor. Management Systems in Production Engineering No. 3(11)

D. Palka, A. Wieczorek. (2017) Postęp techniczny - wybrane problemy oraz propozycje ich rozwiązania. Systemy Wspomagania w Inżynierii Produkcji Vol. 6; Iss. 6

P. Sobota, R. Mann, A. Bujnowska. (2018) Doświadczalne badania położenia ogniw na bębnie łańcuchowym o dużym stopniu zużycia. Management Systems in Production Engineering No. 7(2)

J. Suchoń. (2012) Górnicze przenośniki zgrzebłowe - Budowa i zastosowanie Vol. 1/2. ITG KOMAG

J. Suchoń. (2012) Górnicze przenośniki zgrzebłowe - Teoria, Badania, Eksploatacja Vol. 2/2. ITG KOMAG

D. Szurgacz, P. Szolc, G. Cuber. (2019) Rozwój kompleksu ścianowego w oparciu o doświadczenia ruchowe na przykładzie KWK ROW Ruch Chwałowice. Systems Supporting Production Engineering No. 8(1) Górnictwo - perspektywy i zagrożenia

P. Świerk, K. Foks, M. Wilczak, W. Ziewiecki. (2016) Monitoring pracy maszyn i urządzeń. Systems Supporting Production Engineering No. 1(13) Górnictwo Perspektywy i zagrożenia

A.N. Wieczorek, W. Polis. (2015) Operation-oriented method for testing the abrasive wear of mining chain wheels in the conditions of the combined action of destructive factors. Management Systems in Production Engineering No. 3(19)

D. Wyciszczok, S. Wyciszczok, B. Karczkowski. (2016) Urządzenie do mechanizacji robót pomocniczych - urządzenie UPZ-1 do prostowania zastawek przenośników zgrzebłowych w ścianie. Systems Supporting Production Engineering No. 1(13) Górnictwo - Perspektywy i zagrożenia 


\begin{abstract}
.
The publication presents the assumptions of the unification process of machines and equipment produced by Jastrzębskie Zakłady Remontowe Sp. z o. o. and operating at the coal mines of the JSW Capital Group. It outlines a solution adopted by JZR Sp. z o. o. addressing this issue. The authors identify the potential benefits of the process to the entire Jastrzębska Spółka Węglowa Capital Group, but they also mention the risks that may arise during its implementation. The publication also presents the first results of the unification, observed on the basis of the unified equipment and machinery of the coal clearance system for transporting people, coal and materials, which has already been put into operation in underground mining excavations. It also includes a chapter devoted to the influence of the unification on the development of "technical thought," i.e. on the innovativeness of the equipment for transporting people, coal and materials newly produced by Jastrzębskie Zakłady Remontowe Sp. z o. o. which are to be implemented in the near future. New, innovative solutions are presented, which were introduced both in the unified transport devices such as chain and belt conveyors and in devices cooperating with them, i.e. lump breakers, pushing devices and other accessory equipment for the conveyors.
\end{abstract}

Keywords: unification, transport, chain conveyor, belt conveyor 